\title{
Place and lifestyle migration: the discursive construction of 'glocal' place-identity
}

\author{
Kate Torkington \\ Universidade do Algarve \\ ktorking@ualg.pt \\ Postal address: Universidade do Algarve, ESGHT, Campus da Penha, 8005-139 Faro, \\ Portugal.
}

\begin{abstract}
International lifestyle migration is a rapidly growing worldwide phenomenon. Within Europe, increasingly large numbers of northern Europeans are moving south in search of what they perceive as a better quality of life. The typical representation of this form of migration suggests that it is consumption-led, tourism-related and leisure-based; it is to be located within late modern, global, elitist, borderless and highly mobile social practices. The question arises as to the role of local place in this type of migration process and in the construction of individual and collective social identities. Using data from advertising texts produced by a residential-tourism resort and from in-depth interviews with British residents in the Golden Triangle area of the Algarve, Portugal, this article explores the relationships between discourse, identity, g/local place and lifestyle migration.
\end{abstract}

Globalization and time-space compression (Harvey, 1989) have led to a growing sense that all places in the world are accessible to many of its citizens, creating what Urry (1999/2003) has called a 'compulsion to mobility', at least amongst those who are freely able to move. As Elliot and Urry (2010: 3) note, questions of identity in the present era have become 'fundamentally recast in terms of capacities for movement' as 'the globalization of mobility extends into the core of the self'. Since lifestyles in the 'rich north' have become increasingly globalised and mobilised, the formation of privileged identities has become enmeshed with privileged (and exclusionary) mobility regimes and access to what Urry (2007) has called 'network capital'. Today's global elite, or 'globals' (Bauman, 1998) are characterised not only in terms of their economic wealth and possessions, but also by their 'mobility status' and the 'mobile lifestrategies' they employ to forge their social identities and networked social relations. It appears that, in the twenty-first century, the mobile lifestyles of these 'globals' has become the normative ideal (Elliott \& Urry, 2010: 82).

On the other hand, it makes sense to ask about the role of local place in the formation of individual and collective identities of those who are on the move in ways that are characteristic of an increasingly global and mobile society, including contemporary forms of migration. The global-local dialectic suggests a way of looking 
at the social world that rejects the view of the local and the global as being entirely distinct, separable spheres of social organization and action. According to Amin (1997), we should rather, in the contemporary world, consider them to be interactively and relationally (although not necessarily symmetrically) bound to one another. This relational interplay between the global and the local, or what Robertson (1994; 1995) termed 'glocalisation' as a means of highlighting the co-presence of both universalising and particularising tendencies in processes of globalisation, inevitably impacts on social practices, relations, identities and meanings. Moreover, place-making practices at all levels (including therefore the material and the semiotic) are increasingly bound up with the cultural identity 'glocalisation projects' (Guilianotti \& Robertson, 2007) that result from mobilities of various types.

Southern European tourism destinations are prime candidates for cultural glocalisation projects: as 'places to play' they are constantly made and re-made by the interaction of tourism-based mobilities and the 'performances' that are played out both locally and, simultaneously, on the global stage (Sheller \& Urry, 2004: 4). Whilst Sheller and Urry stress the way in which places are performed through embodied play, in this article I explore how such places are performed in and through discourse, and how this impacts on identities (of both people and places). More specifically, I focus on the discursive construction of a 'glocal' form of place-identity within the context of the growing social phenomenon of lifestyle migration from the north to the south of Europe. The research site is a particular area of the Algarve, in Portugal, which has been attracting growing numbers of northern European lifestyle migrants (predominantly British) over the past two decades. Two types of data are used: promotional texts produced by a well-known 'integrated resort' ${ }^{1}$ in the Algarve and interviews with British lifestyle migrants who live in the area. ${ }^{2}$ In contrast to the other pieces in this special issue, therefore, the focus of this article is an extra-urban, rather than an urban, 'imaginary'; however, as we shall see, the 'urban' (as a place to escape from) remains an implicit point of reference for many of the lifestyle migrants interviewed, while the discursive construction of this utopian 'glocal imaginary' may be seen to share many similarities with that of the cities featured in the other articles.

\section{Lifestyle migration}

Lifestyle migration can be understood as a contemporary form of migration by relatively affluent individuals searching for a particular kind of lifestyle (Benson \& 
O'Reilly, 2009). As a social phenomenon it is very different from more traditional migration patterns, for it is clearly not motivated by economic or political factors. International lifestyle migrants are not post-industrial migrants seeking employment in a more de-regulated and flexible labour market, nor are they part of the growing transnational flows of corporate and intellectual elites (for if work is involved, it is rather a means to an end). They are people who have made a conscious choice not only about how to live but also about where to live (Hoey, 2005). Whilst the lifestyle orientations of these migrants may differ, perhaps the one unifying factor of this group is their belief that a change of residential place will lead not simply to better 'opportunities' in life, but rather to something which might be loosely described as achieving a better quality of life through a change in lifestyle.

Lifestyle migration is often seen as a reflection of counter-urbanization movements, a search for the 'rural idyll' (O'Reilly, 2007c) whereby the countryside is perceived not just as a backdrop, but as a 'therapeutic landscape' (Hoey, 2009) and the key to a more fulfilling way life (Benson, 2009, 2010). The Algarve, whose inland areas remain relatively unspoilt and scarcely populated, certainly has its share of northern European migrants who leave their urban surroundings to seek out the simplicity and perceived 'authenticity' of the 'good life' through some degree of self-sufficiency in isolated rural settings. On the other hand, for many people nowadays the rural idyll is more likely to be imagined on the basis of tourism experiences and representations, rather than on the reality of a truly rural existence. Thus, 'idyllic' retreats from urban life are not confined to genuinely rural landscapes, but are also imagined as being located along the coastlines of southern Europe, for example, as lifestyle migrants seek out places that, having been already developed for tourism, have been tamed, sanitised and rendered familiar enough to normalise a potentially (overly) exotic experience (Neal, 2007). The paradox, of course, is that through tourism and indeed the phenomenon of lifestyle migration, these coastlines are becoming increasingly urbanised.

Macro-level factors that have enabled the trend of international lifestyle migration to flourish are those typically associated with globalization (O'Reilly, 2007a, 2007b), such as the spread of mass information and communications technologies; expanding networks of faster and cheaper forms of transport; the general rise in living standards in the Western world, increased amounts of and commitment to leisure time as well as increased opportunities for flexible forms of working lives and early 
retirement, and, importantly, the development of mass tourism and related infrastructures. The phenomenon within Europe has also been greatly aided by the opening up of intra-EU borders and the relaxed regulations among EU member-states regarding residency and the mobilisation of personal finances.

Social changes in the late twentieth-century have also been far-reaching in other, less tangible ways. Social differentiation has become less dependent on a fixed social hierarchy and individuals are correspondingly less constrained by traditional social structures and categories (Beck, 1992; Beck \& Beck-Gernsheim, 2002; Giddens, 1991). One of the decisive features of late modernity in Western society is the process of 'individualization' (Beck \& Beck-Gernsheim, 2002). According to these authors, this is not a social condition that is arrived at by the free will of individuals, but one that is required by the complex, non-linear systems of the present era. Thus, active contributions by individuals 'to create, to stage manage, not only one's own biography but the bonds and networks surrounding it' (Beck \& Beck-Gernsheim, 2002: 4) are not merely permitted, but demanded.

In a similar fashion, Giddens has argued that late modern subjects face both the burden and the liberation of constructing their own identities, for "we have no choice but to choose how to be and how to act' (Giddens, 1994: 75). According to this argument, self-identity is constructed through what Giddens (1991) calls 'the reflexive project of the self'. The concept of lifestyle in contemporary society is therefore crucial since it is a fundamental part of this project. A lifestyle, which Giddens (1991: 81) defines as 'a more or less integrated set of practices which an individual embraces, not only because such practices fulfil utilitarian needs, but because they give material form to a particular narrative of self-identity' might thus be seen as a kind of template for the narrative of the self. The quest for the right kind of lifestyle to make a statement about who one is or wants to be can be argued, then, to be an integral part of the late-modern social world, at least for its more privileged citizens. Furthermore, for the materially privileged, the spatial location of social activities is increasingly a matter of choice as it 'becomes more and more bound up with the reflexive project of the self' (Giddens, 1991: 147). Lifestyle decisions therefore include the decision as to which residential place might enable one to build a coherent narrative of the self and project the right sort of public presentation of the self, as well as fulfilling more personal, emotional needs.

The convergence of these factors, among others, has created the conditions whereby increasingly large numbers of northern Europeans are moving south in search 
of a lifestyle that they imagine will entail a better quality of life. The typical discursive representation of this form of migration (fuelled by television shows and other forms of the mass media including lifestyle magazines and the internet) suggests that it is consumption-led, tourism-related and leisure-based. Buying one's own 'property' seems to be an essential part of this type of migration process, stemming from an ideology that associates the concept of 'home' and 'belonging' with land and property ownership and thus staking a claim to place. The favoured destinations are typically areas in southern Europe that are already associated with and developed for tourism and leisure, and which are perceived as affording not only the warm and sunny climate that is so often associated with 'the good life' by northern Europeans, but also the more relaxed and sociable lifestyle that is associated with southern European cultures. Thus, international lifestyle migration is often represented as a form of escape, a 'living of the dream'. The search for 'a place in the sun' may indeed be thought of as being both literal and metaphorical, since the figurative expression suggests a position of favour or advantage. As Benson (2011) rightly argues, following Salazar (2010), the migration process is as much about mobile imaginaries as physical movement. However, to return to the point that as a social phenomenon, lifestyle migration is, per se, restricted to those who are materially 'relatively affluent', it is important to remember that in reality, any attempt to 'live the dream' requires more than imaginative travel.

In sum, the phenomenon of lifestyle migration could therefore be argued to be located within late modern, global, elitist, borderless and highly mobile social practices. The ability to become a successful international lifestyle migrant depends not only on one's economic capital, but also on possessing a high level of 'network capital' (Urry, 2007). This type of capital engenders the 'real and potential social relations that mobilities afford' (ibid.: 196) and thus highlights the capacity for privileged social groups to live 'spread-out lives' that are simultaneously relational, connected and embedded (ibid.: 228). However, questions about the role of local place in this type of migration process inevitably arise, including questions as to the relative importance of a particular destination place as a motivating factor for moving abroad and how local place shapes and is shaped by the social identities of migrants. One of the ways in which these questions can be addressed is by exploring how discourse mediates the link between place and identity. 


\section{Discourse and social identity}

Discourse has become a core concept across the social sciences. It can be understood as being both language in use (i.e. 'real' language used in 'real' social world situations) and a form of social practice. This means that there is a dialectical relationship between any discursive event and the social world in which it is embedded. In other words, discourse is socially constitutive as well as being socially conditioned - through a variety of discursive practices, it (re)produces and shapes objects of knowledge and social identities as well as being (re)produced and shaped by them (Fairclough \& Wodak, 1997: 258). This relationship between society and discourse is mediated by cognitive processes such as thought, perception and mental representation (van Dijk, 2009).

Current thinking on how discourse and identity are interrelated is grounded in the idea that, as social beings, we present and perform various 'selves' to others through discourse. As such, identities are multiple, flexible, and often strategically deployed. Furthermore, they are jointly constructed in social interaction. This approach to discourse and identity is aligned with the general, broad perspective of social constructionism, from which comes the assumption that identity is neither a given nor a product but rather a process that is embedded in social practices, including discursive practices. There is nothing given or 'natural' about being part of a social category or group (De Fina, Schiffrin, \& Bamberg, 2006), since people are constantly engaged in a dynamic and shifting process of positioning themselves and others. This can be achieved in a variety of ways, including by identifying with or against certain places. In this way, identity can be thought of as being both a representation and a position in discourse (Benwell \& Stokoe, 2006: 116).

Of crucial importance here is the concept of social representations (Moscovici, 1984, 2000), which provide the shared framework of reference needed for communication to take place. These representations, which Koller (2008a) suggests are more accurately called 'socio-cognitive representations' (SCRs), comprise both cognitive and affective elements. Indeed, for Koller, collective social identities are socio-cognitive representations, which, like any SCRs, including those which give meaning and identity to places, are socially and discursively constructed and thus liable to constant reproduction, negotiation, reformulation or challenge in social interaction. On the other hand, we also use discourse to project a more personal facet of identity. For most people, it is important to be able to project a consistent and stable self identity 
that reveals a basic sense of autonomous agency through a coherent life story (Johnstone, 2008). In short, we can therefore talk of both 'collective' and 'individual' social identities which are inevitably intertwined and constructed in large measure in and through discourse.

\section{Place and place-identity}

The concept of 'place' is problematic in that it is both simple to understand in an everyday sense and yet almost impossible to pin down once we attempt to go beyond this (Cresswell, 2004). However, for the purposes of this paper, I will limit myself to the rather simplistic definition that a place is a meaningful location which is socially (and therefore, in part, discursively) constructed. As such, places are fluid and shifting rather than static entities and, like people, they can have multiple and complex identities.

In the 1970s, the so-called humanistic school of geography began to seriously reflect on the central phenomenological questions of how people create a meaningful world and meaningful lives for themselves in that world. It was suggested that there is a universal, and profound, human need for associations with significant places, amongst which the 'home' place is the most significant (Relph, 1976; Tuan, 1974). Notwithstanding subsequent critiques of these early texts (see, for example, Massey, 1994), the exploration of the affective bonds between people and places by humanistic geographers became a cornerstone for the concept of place-identity. Despite (or perhaps because of) the sense of diminishing spatial barriers in the world, some would argue that place-bound identities seem to have become more rather than less important (Harvey, 1993: 4). Yet although 'attachment to place remains remarkably obdurate' (Savage, Bagnall, \& Longhurst, 2005: 1), the attachments to places that constitute a sense of belonging are likely to be very different in the late modern world than they were in previous times. Belonging is no longer necessarily so much an attribute of being 'born and bred' in a place, but can arise when a chosen place of residence is perceived as valuable due to its congruence with lifestyle and life-story requirements as well as through its connection to other significant places (ibid.: 55).

The relationship between the identities of people and places is dialectical: whilst places are produced and given (potentially multiple) meanings and identities by people, places may also be said to shape people in some way. Therefore, place-identity can be understood as the interactive relationship between place(s) and the multiplicities of the individual and collective self. The concept of place-identity thus includes relationships 
that enhance or impede feelings of belonging. Furthermore, it is increasingly being argued that it is in large part through discourse that places are imaginatively constituted by and constitutive of who we are (e.g. Benwell \& Stokoe, 2006; Dixon \& Durrheim, 2000). It is upon the discursively constructed aspect of place-identity that this paper focuses.

\section{Research site}

The most popular site for lifestyle migration in Portugal is doubtless the Algarve. This southernmost region of Portugal has seen massive tourism development since the 1970s, concentrated along the southern coastal strip. Since the 1980s, there has been a corresponding increase in the number of northern European lifestyle migrants, with the largest national group being the British. The British Embassy in Lisbon estimates that there are currently 60,000 to 70,000 British nationals living part-time or permanently in Portugal, with around 40,000 of these in the Algarve. ${ }^{3}$ Since the official total population of the Algarve region is around 400,000, the number of British nationals is equivalent to $10 \%$ of the total regional population.

My research is based in an area of the Algarve known among its British residents as the 'Golden Triangle'. The area, in the Concelho (district) of Loulé, includes several upmarket golf and beach resorts. These resorts were first developed for tourism some forty years ago on sites which previously had been scarcely populated and were characterized by sand dunes, scrubland, pine woods and agricultural smallholdings. The construction of 'luxury' resorts (often referred to in Portuguese as urbanizações, or 'urbanizations') in such an undeveloped, rural setting by the sea led to a phenomenal increase in the value of the land, and the coining of the 'Golden Triangle' name by the (predominantly northern European) real estate agents operating in the area, since land prices rose rapidly to become reputedly among the highest per square metre in Portugal, attracting foreign investors as well as northern European migrants.

Although this trend began as an international retirement migration phenomenon (see, for example, King, Warnes, \& Williams, 2000; Williams \& Patterson, 1998) it now encompasses all age groups, including families with young children. There are different types of migration processes in evidence, including second home 'residential tourism', temporary (short-term) migration, seasonal migration and more permanent settlement. I am particularly interested in 'full migrants' (O'Reilly, 2000, 2007a), as these are people who consider their Algarvian home to be their only current home (i.e. 
in the sense of place of residence). It would be expected that the role of local place is most prominent in the migration process for these migrants, since they have more at stake in terms of settling into the area, making a home, and feelings of belonging.

\section{'Residential-tourism' resorts}

It has long been argued that the antithesis of place - what the humanistic geographer Relph (1976) termed placelessness - is relentlessly spreading across the globe and eroding our so-called 'sense of place' as a meaningful parameter of our experience of and identity within the world. Relph defined placelessness as 'the casual eradication of distinctive places and the making of standardized landscapes that results from an insensitivity to the significance of place' (1976: preface) and illustrated his argument through a wide range of examples including tourist resorts, theme parks and shopping malls, which he labelled 'inauthentic' places. Of course, such places are designed as 'passing through' places.

At first glance, it would seem that the proliferation of residential developments in tourist destinations around the world which are being built to cater for the international lifestyle migration phenomenon might fit the description of 'inauthentic' places. A brief tour of internet sites promoting such developments in different countries reveals their remarkable visual resemblance, although they might be as far afield as Portugal, Spain, Egypt, Florida, Brazil or Panama. According to Fairclough (2009: 165), discourses may be 'operationalised' in different ways, including physical materialization, such as architecture and new ways of organising space. Thus, the similarities in these developments might be thought of as a kind of intertextual chain in the global architectural discourse of lifestyle migration: the strikingly similar, low-rise condominium buildings or terraced 'villas' clustered around swimming pools and set among landscaped gardens with bright green lawns dotted with palm trees create a sense of globalised, homogenised style which is immediately identifiable with wealth, conspicuous consumption, privilege and social status, as well as tourism and leisure.

Yet a closer look at the architecture can reveal an interplay between the semiotics of the global and the local, for these buildings often incorporate local features into their design - even though these designs might be somewhat out of context from a local perspective. A style of villa that is favoured by wealthy British residents in the Algarve, for example, blends features of grandiose British colonial style (verandas, colonnades, porticos, wide flights of steps leading down into the 'garden' area etc) with 
'typical' Algarvian features, such as the ubiquitous Algarve chimney (whose striking design is said to have Arab influences $)^{4}$ and the distinctive four-sided pyramid style of the tesouro roofs of the townhouses dating back to the C16th. Both the Algarvian chimneys and the tesouro roofs are themselves traditionally external displays of wealth. The more intricate and decorative the lattice-work on the chimney, the wealthier the owner of the house was deemed to be. As for the roofs, thought to have been influenced by Asian architecture ${ }^{5}$, traditionally one was erected over each division in the house, thus allowing the numbers and sizes of the rooms to be visible from the outside (see figures $1-3$, in appendix).

This form of architectural 'glocalisation', which is both synchronic (global resort architecture with local influences) and diachronic (different historic-cultural influences in the local elements) certainly features in the discursive practices of the real estate sector. Under the strapline 'BLENDING TRADITION WITH CONTEMPORARY STYLE', the real estate brochure of a well-known resort in the Golden Triangle area boasts:

Vale do Lobo relishes the challenge of seamlessly blending the tradition of its homeland with the best of modern styles and materials. These properties intertwine local traditional architecture with contemporary design elements - for example, stone-clad walls and exposed beams might counteract a modern glass and stainless steel staircase. ${ }^{6}$

Another example of the 'glocalising' of these places is that integrated resorts are increasingly being built in the form of 'villages' - a word which evokes representations of close-knit community life; places where everyone knows each other and which are spatially organised around central cultural concepts such as a church and/or a village 'square' or similar public space. ${ }^{7}$ It could be argued that in the fragmented and individualised late modern age, a 'nostalgic' sense of community has become a highly commercialised trope in place advertising and branding, through which 'consumers are able to forge an ephemeral sense of interpersonal connection via common consumption interests' (Thompson \& Arsel, 2004: 639). This has clearly not escaped the attention of the resort developers at Vale do Lobo, which is spatially organised around two social and commercial hubs - the Parque do Golfe (Golf Centre) and the Praça (the Portuguese word for public square) - which provide, among other things, a range of shops, a bank, a post office, an art gallery, a 'wellness centre' with spa, a medical centre, a children's play area, several restaurants and bars, the golf club and academy 
and a communal outdoor swimming pool. The resort is divided into several residential bairros (neighbourhoods). Although the resort is not 'gated' and has open access, there is nonetheless a monumental entrance complete with archway, fountains and the resort name, giving a definite sense of entering a bounded space. The main thoroughfare runs in a loop around the resort, bringing any casual sightseers back to where they started.

So are resorts such as this really examples of 'placelessness'? I would suggest that despite their somewhat artificial and standardized appearance, these resorts are clearly meaningful places for those who use and inhabit them. For those who have the privilege to be able to freely and actively choose their place of residence, the decision will be based to some extent on lifestyle considerations, since choice of residential place is a significant lifestyle indicator and therefore an integral part of the occupants' selfidentity. For many, the place in which one lives is simultaneously a base for the activities and practices of daily life and a fundamental part of one's life-story. It is a place that is embedded in a lifestyle project which is subject to constant revision and change in order to preserve or enhance one's position in society (Ærø, 2006). Places such as Vale do Lobo have clear lifestyle connotations for those who choose to live there; indeed they exude a sense of lifestyle based on affluence, consumption, leisure, and exclusivity. These types of places, and the discursive practices surrounding them (see below), therefore clearly project something about the collective social identity of those who live there.

\section{Place branding and local place}

Discursive practices such as place branding reinforce collective socio-cognitive representations of the place among particular (specifically targeted) groups of people. In the case of lifestyle migration destinations, this inevitably includes the discursive construction of place through both tourism and real estate advertising practices, in the form of texts which are increasingly omnipresent both in situ (as part of the relatively fixed linguistic landscape ${ }^{8}$, e.g. on billboards) and elsewhere, in more mobile formats (e.g. on the internet, in travel brochures and 'flyers', in the 'lifestyle' sections of the media, TV programmes and so on).

In other words, although individuals will doubtless hold their own place images, since their exposure to different aspects of that place will be different, sometimes these images are more widespread and pervasive, being shared by members of a social group; they are stereotypical images that have been subjected to extreme simplification. These 
images, or socio-cognitive representations, establish social identities and relations via repeated communication and negotiation through discursive practices (Koller, 2008a, $2008 \mathrm{~b})$. It is crucial to acknowledge and understand the role of place branding in generating, privileging, and reshaping place identities (Mayes, 2008), which it plays through communicating value-expressive attributes that are linked to both place and individual and collective self-expression. The semiotics of the place must therefore correspond to the expectations of the lifestyle experience which have already been created in the imagination of the prospective buyer through previous exposure to discursive practices such as branding.

A potential pitfall in place branding is, however, the very fact that it has become such a global and globalizing force; there is a clear tendency towards the global homogeneity of brands and the practices (including discursive practices) surrounding them. On the other hand, there is also a noticeable increase in heterogeneous local adaptations and meanings of brand values and discourses (Koller, 2008a). As we have seen, architectural and spatial organisation practices are tending towards this kind of glocalisation. Brand managers are certainly aware that a key factor in branding is differentiation, particularly in tourism environments where most destinations can make the same claims to have luxury resorts, a whole host of attractions, a 'unique' culture, heritage, landscape, people, and so on (Morgan \& Pritchard, 2004).

One way of differentiating resort areas is simply to make the resort name itself the essence of the brand; that is, to ensure that the brand name automatically conjures up a socio-cognitive representation of place that resonates with the perceived self image of the targeted consumer segment. As such, brand managers 'appeal to consumers' values and self-images and in doing so they are thereby appealing to the powerful discourses which have shaped those self-same values and images' (Morgan \& Pritchard, 1998: 142). Certainly those involved in the branding of Vale do Lobo discursively construct place (through its toponym/brand name) and lifestyle as being mutually dependent. Advertising straplines make the specific claim that place is lifestyle: 'Vale do Lobo: an exclusive way of living'. The architecture and spatial organisation are the materialised features of the place brand. The brochure extract below makes it clear how important the spatial component is in the branding process, with a strong emphasis on 'location'9 as well as the use of the theatrical nouns 'setting' and 'backdrop', which position the place as the essential 'scene' in which a particular lifestyle can be played out and performed: 
The recently launched Vale Real - Vale do Lobo's latest development - is already generating a huge amount of interest due to its spectacular setting and prime real estate location. Superbly positioned golf front plots await the discerning client, offering an unbeatable location for a number of exclusive new homes with the beautiful championship golf course - the Royal - creating the perfect backdrop [bold/italic type emphases are my own]

As already noted, the spatial organisation of the resort, with its clearly delineated boundaries, residential areas and central public spaces, was seemingly designed to create a sense of community. This is also strategically used in the place-branding discourse: the Vale do Lobo website ${ }^{10}$ claims to offer 'an outstanding year-round community spirit' which has 'grown naturally over the resort's 45 year history', thus also invoking a temporal claim to both a stable ('year-round') and historic ('45 year') identity. The claim is backed up by a direct quote from 'proprietors' living in the resort, who use the trope of 'community' to implicitly stress the meaningfulness of Vale do Lobo (in contrast to other resorts) as an 'authentic' place to live where one can experience a communal sense of belonging:

We love the sense of community here. There are a lot of things we can do with our friends (...) it's not like in some resorts where you don't know your neighbours.

To summarise, the branding process of Vale do Lobo is concerned not only with projecting an image of an upmarket tourist resort, but also a place to live. Brands can impact on social identities by providing membership in imagined communities (Anderson, 1983). A 'glocalised' brand offers membership in a hybrid imagined community (Koller, 2007); one that is simultaneously global (in this case as part of the global elite who have the resources and capital to become lifestyle migrants) and local (as a resident in a particular place and community). In today's 'experience economy' (Pine \& Gilmore, 1999), consumers want to purchase experiences. Buying a home in a lifestyle migration destination is perhaps as much about buying an (imagined) lifestyle experience as investing in material property. In this way, the Vale do Lobo brochure can claim that 'Property Owners at Vale do Lobo have not just purchased a dream home, but a dream lifestyle'. Place brand managers are obviously concerned with reinforcing the idea that a particular desired lifestyle goes hand in hand with a specific 'local' place, since they are positioning that place in a competitive global market.

However, the 'locality' of such places is carefully constructed as a bounded container for the performance of an elitist, leisure-based lifestyle. As one research 
participant put it, the sense of 'community' among the 'ex-pats' in Vale do Lobo is so strong that 'you don't really need to go outside much anywhere'. One of the recurrent lexical themes in the Vale do Lobo advertising is that of 'exclusivity'. One billboard located just outside the resort promises, in huge gold lettering, 'EXCLUSIVITY AWAITS YOU'. Through the nominalization, 'exclusivity' becomes something almost tangible by making it synonymous with the place itself. This is reiterated through the new resort slogan, 'Exclusive living since 1962', which has replaced the former slogan 'Europe's finest luxury resort' and thus also reiterates the possibility of the place offering a residential way of life rather than a temporary tourist stop-over. The images that accompany the texts are intertextual references from typical tourism promotional media, showing luxurious 'homes' with swimming pools, swathes of verdant green golf courses, beaches at sunset. The people shown are generally engaged in the types of activities associated with these leisured-lifestyle signifiers. These are generic, 'global' images in that they mobilise apparently 'placeless' settings which could be one of any number of tourist destinations around the world. Local emplacedness is typically signified by aerial shots (carefully framed so as not to include anything beyond the boundaries of the resort), giving a bird's eye (or aeroplane seat) view from above. This not only creates a distancing and detaching effect from the place but also symbolically invests the viewer-as-potential-property-buyer with power via the 'god-like top-down' angle of the shot (Kress \& van Leeuwen, 1996: 152). Moreover, the salient language of the texts is English, reinforcing the message that Vale do Lobo is a global stage. Thus, the identity of the place is forged with a sense of symbolic distinction and separation from the 'rest' of the local place within which it is geographically, at least, inserted. However, the question remains as to how lifestyle migrants themselves equate local place with their lifestyle and, indeed, their social identity. The final section of this paper briefly discusses this.

\section{Lifestyle migrants' own constructions of place-identity}

So far in this discussion there has been an underlying assumption that lifestyle migrants gravitate towards the kind of resort described above when they relocate to southern Europe. This is, of course, by no means the case. In the Algarve, in parallel to the growth in numbers of migrants who are settling in the resort areas and developments along the coast, there are also increasing numbers who opt to live away from the coast, in small towns and villages or in the more rural foothills of the hinterland. 
I next consider some data from interviews carried out with British migrants in and around the 'Golden Triangle' area of the Algarve. The in-depth interviews from which the data extracts are taken aimed to elicit narrative accounts of moving to and living in the Algarve. All the participants can be considered full migrants since the Algarve is their only current place of residence. To recap, the questions underlying this paper are to do with the role of local place in the international lifestyle migration process and in the construction of migrant place-identities. The interview data allows an investigation of how place-identity work is done in talk. This brief exploration concentrates on three aspects: to what extent the local destination place is constructed as an important factor in the decision-making process to move abroad; how local place is represented and evaluated in accounts of living in the Algarve and how the discursive marking out of spatial boundaries is used as a discursive strategy for constructing placeidentity.

\section{How local place features in moving stories}

Since lifestyle migration can be thought of as a global trend with myriad relocation possibilities throughout the world, it is interesting to examine if a specific local place is constructed as having special importance as a motivating factor in migrants' 'moving stories' (that is, their narrative accounts of how the move came about). For some migrants, their more permanent move is a progression from repeated holidays or second-home ownership in a particular place, meaning that the place is already an integrated part of the migration trajectory. However, most of the participants in my research claimed to have made the decision to move based on very little first-hand experience of the place. Gillian, ${ }^{11}$ for instance, describes it as 'quite an impulsive move', taken after she and her family visited the Algarve for the first time. They had stayed for just five days with British friends already living in Vale do Lobo and, having thus 'sampled the lifestyle', she 'completely fell in love' with the place. Likewise, Jean and her husband had only visited the Algarve once before they moved there, staying in a friend's villa where, she says, 'we met a lot of ex-pats' and experienced 'the lifestyle and everything else'. Again, her account of what initially attracted them to move to the Algarve doesn't go much further than a vague reference to 'the lifestyle' which is evidently associated with the 'ex-pats' they met. The lack of previous knowledge of the place is even more evident in Marion's vague and hesitant account of what her impressions of the Algarve had been before moving: ${ }^{12}$ 
$\mathrm{K}$ what- what sort of impression did you have of the Algarve before you came to live here, did you [know a lot about it] knew about the Algarve but I honestly- I mean my geography's terrible

$\mathrm{K} \quad \mathrm{mm}$

M I knew Algarve and Portugal were sort of (.) the same but I don't know whether I just thought the Algarve was Portugal, do you know what I mean

$\mathrm{K}$ yeh, yeh

M um (.) and apart from the fact that yeh it would be sunny (.) possibly (.) um:: with the sea and the beach I think that's about it!

$\mathrm{K}$ yeh

M so I really um didn't know anything about the Algarve

Marion's previous 'knowledge' of the Algarve was apparently limited to a mental representation based on the $3 \mathrm{~S}$ 's (sun, sea and sand) that for many northern European tourists are the fundamental prerequisites for a summer holiday destination. The beach is, after all, one of the most emblematic sites for staging the performance of the leisured lifestyle of the affluent classes (Bærenholdt, Haldrup, Lardsen, \& Urry, 2004). In fact, for many migrants, the Algarve was initially just one destination option in what appears to be a range of potential places. For Peggy and her husband, it is clear that both the Algarve and Florida were perceived as having the right lifestyle affordances - including a good climate, golf facilities, the right type of housing - but, she says, they eventually 'picked' the Algarve because of its proximity (in flying time) to the UK. Harry's account of his family's move is remarkably similar; it was a spontaneous ('out of the blue') decision made between two options, the rather vague 'America' and the Algarve. Again, the Algarve was eventually chosen because of the greater ease in getting 'back home' if necessary:

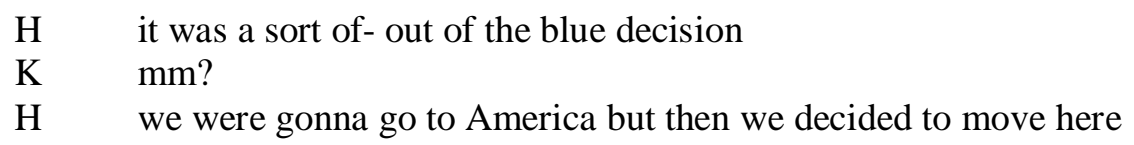

In short, the place itself does not initially seem to have played a large motivating role in the move abroad for these migrants beyond being vaguely imagined as an appropriate setting for lifestyle aspirations; a place chosen from a mental 'catalogue' of suitable destinations that are perceived to 'fit' with the sought-after lifestyle. On the other hand, the extract also illustrates the extent to which mobility plays a part in the imagined (and embodied) lifestyle of such migrants, for the possibility of 'return' - 
even if only on a temporary basis to visit friends and family - is a constant preoccupation.

\section{Representing and evaluating local place}

The representations of the Algarve that emerge as the interviewees recount their experiences after the initial move are generally rather stereotypical positive evaluations based on lifestyle affordances, often set up in direct contrast with negative (and similarly stereotypical) representations of the place left behind (vaguely referred to as 'the UK' or 'England'). The same repertoires are drawn upon repeatedly, meaning that collective social representations can be inferred. These representations are no doubt reinforced through the constant interaction among British lifestyle migrants, who naturally wish to share their experiences.

Attitudinal positioning can be carried by individual words (typically adjectives that express attributes directly associated with place/lifestyle) that work to build up evaluative representations of place that run throughout the data (see table 1 below).

\begin{tabular}{|c|c|c|}
\hline & $\begin{array}{l}\text { 'there'-place } \\
\text { England / the UK }\end{array}$ & $\begin{array}{l}\text { 'here'-place } \\
\text { (Algarve/Portugal) }\end{array}$ \\
\hline $\begin{array}{l}\text { Adjectives used by } \\
\text { participants } \\
\text { expressing attributes } \\
\text { directly associated } \\
\text { with place/lifestyle }\end{array}$ & $\begin{array}{l}\text { depressing } \\
\text { cold; wet; grey; } \\
\text { hectic; busy; } \\
\text { regimented } \\
\text { rough } \\
\text { expensive; extortionate }\end{array}$ & $\begin{array}{l}\text { perfect; ideal; lovely; pretty; } \\
\text { beautiful; fantastic; } \\
\text { wonderful } \\
\text { warm; hot; } \\
\text { sunny; bright; clear } \\
\text { relaxed; slow; peaceful; } \\
\text { quiet } \\
\text { safe } \\
\text { reasonable; cheap; } \\
\text { affordable }\end{array}$ \\
\hline
\end{tabular}

Table 1: Attitudinal positioning in representations of places

Contrasting evaluations can be spread across stretches of discourse. For Jean, the Algarve affords a relaxed, sociable lifestyle with plenty of warm sunshine and a reasonably low cost of living, whilst England is a place with a 'regimented' lifestyle, where everything is 'to the clock' and things are made worse by the constraints of cold weather, the high cost of living, too much traffic and a bad diet - people in England eat 'more rubbish and takeaways' as well as 'more processed stuff' and 'packets of stuff'. 
Comparisons of the here/there places are frequently realised linguistically by direct contrastive conjunctions such as whereas:

it's cold in England in the winter no-one actually wants to go outside the door do they whereas in the winter here it's not too bad is it you just put on a jumper and off you go

what $\underline{I}$ love about here is there's no traffic you know you go back to the UK it's like oh my god you can't move for hours whereas here (.)

Representations of place feature strongly in the data as discursive strategies for self-presentation. By discursively enacting attachments through attitudinal alignment to the here-place, the speakers seek to indirectly build a positive self-representation as a migrant who is in control of life-choices. Since these contrasts are often realised using the generalized subject pronoun 'you', we can infer that shared SCRs of the affordances or constraints of place are being drawn upon and used strategically to reinforce a 'common sense', taken-for-granted view of the world:

but to eat out or do anything else out or go to a pub you just couldn't afford it in England whereas here it's the opposite you can go out and eat reasonably and drink reasonably if you want

The discursive construction of place necessarily involves the definition of what lies outside. The juxtaposition of here and there is thus a form of 'othering', helping to reinforce the positive status (and identity) of the 'insider' by rejecting what lies on the outside. In much the same way that 'outgroup derogation' and 'ingroup celebration' are typical discursive strategies that often help to define social group membership (van Dijk, 2009), lifestyle migrants use 'there-place derogation' and 'here-place celebration' as discursive strategies that enable them to stake a claim to affective and ideological belonging to their adopted home-place. Whilst 'there-place' derogation clearly resonates with anti-urban sentiments, and whilst the negative evaluations of the here-place in the data are specifically associated with the encroaching urbanisation which paradoxically stems from the constant construction of ever-more accommodation for tourists/lifestyle migrants, the SCRs drawn upon to celebrate the here-place echo the celebratory discourses of tourism advertising (Caldas-Coulthard, 2008) and seem to mask any real sense of place.

\section{Discursive 'mapping' of spatial boundaries}


Moving to the Algarve, like moving to other southern European holiday destinations, is generally portrayed (in the mass media, through place branding, etc) as an extension of tourism with the potential for an endless holiday. Indeed, the data show that the research participants do, to some extent, represent themselves as having a leisured and leisurely existence living in 'villas' or 'apartments' (rather than 'houses' or 'flats') being constantly outdoors, eating al fresco, playing golf or tennis, swimming in their private pools. Moreover, northern Europeans living in the Algarve are generally represented by their Portuguese 'hosts' as practising 'turismo residencial', or residential tourism. This, however, presents a contradiction in terms (O'Reilly, 2007b, 2009) and it is therefore not surprising that those who discursively orient themselves towards presenting a 'settled' place-identity should reject the transient identity implied by the identification as 'tourist', seeing themselves rather as 'residents'.

Doing 'not a tourist' identity work is something that the research participants actively engage in, creating a definite sense of 'us', the settlers, as in-group, and 'them', the tourists, as out-group. However, the not-a-tourist repertoire involves more than simply stating that one is not a tourist. One of the more subtle ways of doing this identity work involves the discursive 'mapping' of spatial relations by the linguistic marking of imagined boundaries between tourist and non-tourist spaces. Examples from the data include claims not to be living in a tourist area through implicit contrast, e.g. 'I would never like to be where the tourists are'. Another participant told me: 'this is ideal really where we live here because we're not on the tourist track'. Besides spatially positioning her home as being away from tourist activity, which she claims you only witness 'if you go down the road', by not being 'on the tourist track', she is constructing her home-place as being away from the movement of tourists, therefore suggesting a desire to create a more stable and fixed home-place.

These kinds of affirmations come from people who do not live in residentialtourism resorts, but have chosen instead to live away from the coast, even if only at a distance of a few kilometres. They identify strongly against those places, as well as the imagined communities who live in such resorts and the kind of lifestyle they perceive them as having. When I asked Amanda what had led her and her family to settle some kilometres inland, she makes a clear distinction between the 'holiday lifestyle' of people who live 'down towards the coast' and the more 'local' place where she lives, which enables her to feel 'a bit more Portuguesey': 
K why- why did you choose this part rather than- I mean a lot of people choose (.) to be near the (.) coast well not too far from the coast

A yes I wanted to be more (.) would you say a little bit more Portuguesey or:: away from that (.) holiday coming and going it's- people that- some people who live down (.) towards the coast first and foremost live very different lifestyles to us (.) but also (.) more of a holiday lifestyle um I know it's only (.) ten minutes away but- but then that's my perception on it I presume

K yeh

A um (.) but I just wanted to be a bit more in (.) local (.) I mean all our- all our neighbours are all Portuguese

By positively evaluating her neighbourhood as being 'away from that holiday coming and going', this speaker is also stressing the value of fixity 'in' place over continuous movement between places, thus apparently drawing on representations of 'rootedness' in place as an essential component of elective belonging/being 'at home'.

The contrast between the Golden Triangle and the 'real' or 'authentic' Portugal is often drawn upon. One speaker equates the Golden Triangle with a 'bubble' compared with 'the actual towns where there is true Portuguese'. Another, who lives in the town of Almancil (generally discursively 'mapped' as being at the northern apex of the triangle) describes it as 'sort of (.) n:ot completely in the tourist area (.) but not- you know not in a Portuguese place either though (.) sort of on the border'. Spatial formulations are thus used to mark out imagined landscapes. By discursively plotting out tourist and not-tourist spaces, and by constructing one's home-place as being 'outside' the tourist space, a greater commitment to belonging to the local place is being made.

\section{Conclusions}

Glocalisation projects can imply the meshing of the global with the local in new and imaginative ways. The data suggest that the discursive construction of lifestyle migrants' place-identity can be thought of as a glocalised process. The status - and social identity - of lifestyle migrants in their adopted place of residence is ambivalent (O'Reilly, 2007b). On the one hand, they remain in many ways outsiders, positioned from the outside as elite (in terms of material and economic privilege) 'globals' or 'residential tourists' who live in exclusive, self-marginalised spaces. On the other hand, interview data with British migrants in one of the most 'upmarket' and sought-after residential tourism areas in the Algarve suggest that they respond to a basic human need to create meaningful associations with home-places as posited by the humanistic school of geography. As Koller (2007) has argued, in an era marked by the encroaching 
standardisation and uniformity of globalisation and its decontextualised and fragmented lifestyles, consumers are feeling a greater yearning for the 'authentic', the 'traditional' and the 'local' aspects of place, whilst simultaneously enjoying the products, services and amenities available to the mobile, globalised elite. In other words, a 'glocal' place identity seems to simultaneously reject and embrace values that are typically associated with late modern urban cultures.

It might therefore be said that one of the hallmarks of lifestyle migration is the discursive construction of a utopian, glocal place-identity, which could also be thought of as making a (literal and metaphorical) 'glocal place in the sun'. This 'discursive space' (Silverstone, 1998; Wetherell, 2001) is woven from a variety of intertextually and interdiscursively overlapping sources: e.g. place branding practices, tourism promotion, the mass media, and the talk of lifestyle migrants themselves. In other words, discourse about the destination place is simultaneously mobilised via the global stage and fixed in local place, as glocal meanings and identities are forged to create and perform a highly stylised version of the place that fits with the perceived lifestyle requirements and preferred social identities of its new residents. Through discourse that selectively instantiates the underlying networks of SCRs that form people's imaginaries, particular versions of local places can be symbolically reproduced, shaped and transformed.

Localities are socially and, to a large extent, discursively produced through processes of boundary definition. Appadurai has argued that local places such as neighbourhoods are what they are because 'they are opposed to something else and derive from other, already produced neighbourhoods' (1996: 183). As Cresswell (2004: 102) argues, the creation of place necessarily involves defining what lies outside. As shown in the interview data, the consistent use of contrasting discursive representations of places supports the argument that in contemporary times, the 'local' is not seen as a concrete particular in opposition to a general, but rather as a hub in a network that articulates other 'local particulars' that are relevant to one's life story and place-identity (Savage et al., 2005). Positioning the self as being affectively aligned or dis-aligned with interconnected places is an important discursive resource for doing social identity work in interaction, as speakers seek to build a positive self-representation as successful migrants in control of life-choices.

In a world increasingly characterised by the removal of spatio-temporal barriers and the dissolution of traditional social coordinates, those privileged enough to have a 
choice in the matter may well be seeking to 'reassert a sense of belonging in the act of consuming space' (Elliott \& Urry, 2010: 83). In other words, this 'globalization of privatized belonging' (ibid.) has become a mobile life-strategy for creating a sense of feeling 'at home' in order to compensate for having no real sense of physical, cultural or ancestral ties with the place in which they have chosen to live. Interestingly, it appears that privileged mobilities can lead to privileged forms of immobility. As Benson (2011: 226) notes in her ethnographic study of British migrants to a rural region of France, 'success within the destination depended on migrants' achievement of a particular balance between mobility and immobility'. In a similar way, I found that British lifestyle migrants in the Golden Triangle area stress both their emotional and physical fixity in place (with comments such as 'no desires whatsoever to go back to the UK' and 'in two and a half years I've been back two weekends and that's because I absolutely had to'). At the same time, however, the potential for mobility - or 'motility' (Kaufmann, Bergman, \& Joye, 2004) - is an important prerequisite for this elective immobility. The 'motility' of these migrants encompasses both the possibility of 'moving on' to a new destination if the current one no longer fits lifestyle requirements or the ever-present possibility of 'going back' to the UK if and when necessary. As Elliott and Urry (2010: 78) note, the scripts of a networked mobile lifestyle seem to necessarily include the mapping of possible 'escape routes', or 'exits'.

On a final note, it is worth remembering that the concept of glocalisation has also been viewed as encapsulating the idea of social inequality. For Bauman (1998), glocalisation is globalisation for some, localisation for others, in a world where there has been a re-stratification of society based on freedom and movement, or lack of it. Some people are liberated and empowered by global mobilities, whilst others are 'imprisoned' in a specific locality. Paradoxically, hegemonic discourses that (re)produce integrative 'glocal' identities are simultaneously reinforcing the 'glocal' dichotomy that underlies much of the social inequality in the world.

\footnotetext{
1 'Integrated resorts' are resorts developed and marketed for both tourist and residential purposes, with facilities such as golf courses and spas. 'Residential tourism' in such resorts is named as one of the 10 strategic products for the development of tourism in Portugal, according to the Portuguese National Strategic Plan for Tourism (Turismo de Portugal, 2007)

${ }^{2}$ The data come from a larger corpus collected for doctoral research (cf. Torkington, 2011)

${ }^{3}$ Information taken from http://ukinportugal.fco.gov.uk/en (accessed 21/04/09).

${ }^{4}$ The south of Portugal was ruled by North African Muslims for around 500 years, from the C8th to C13th
} 
${ }^{5}$ Goa was colonized by the Portuguese from the early C16th. Algarvian ports were linked to the East by the Portuguese sea trading routes of the $\mathrm{C} 16$ and $\mathrm{C} 17$ th.

6 'Timeless': Vale do Lobo Real Estate brochure [original in English], retrieved from www.valedolobo.com (accessed 16/07/09).

${ }^{7}$ Incidentally, there are a growing number of integrated resorts in the Algarve that are being named with a blend of Portuguese and the English word village (e.g. Areias Village, Colina Village, Alma Verde Village). This is a further dimension of the discursive construction of a glocalised identity, since the local language is combined with the 'global' language of English.

${ }^{8}$ The linguistic landscape is comprised of language in its written form, in the public sphere that is potentially visible to all (Gorter, 2006).

9 The word 'location' has a potentially strong resonance with 'lifestyle' for the British due to the popular lifestyle television series Location, Location, Location, in which 'property experts' help members of the public find their 'dream home'.

${ }_{10}$ www.valedolobo.com (accessed 20 November 2009)

${ }_{11}$ All names have been changed.

12 A transcription key is provided in appendix. In this and all subsequent data extracts, ' $K$ ' is the interviewer.

\section{References}

Ærø, T. (2006). Residential choice from a lifestyle perspective. Housing, Theory and Society, 23(2), 109-130.

Amin, A. (1997). Placing the global. Theory, Culture \& Society, 14(2), 123-137.

Anderson, B. (1983). Imagined Communities. London: Verso.

Appadurai, A. (1996). Modernity at Large: Cultural Dimensions of Globalization. Minneapolis: University of Minnesota Press.

Bærenholdt, O., Haldrup, M., Lardsen, J., \& Urry, J. (2004). Performing Tourist Places. Aldershot: Ashgate.

Bauman, Z. (1998). Globalization: The Human Consequences. Cambridge: Polity

Beck, U. (1992). Risk Society: Towards a New Modernity (M. Ritter, Trans.). London: Sage.

Beck, U., \& Beck-Gernsheim, E. (2002). Individualization: Institutionalized Individualism and its Social and Political Consequences. London: Sage.

Benson, M. (2009). A desire for difference: British lifestyle migration to southwest France. In M. Benson \& K. O'Reilly (Eds.), Lifestyle Migration: Expectations, Aspirations and Experiences (pp. 121-136). Aldershot: Ashgate.

Benson, M. (2010). The context and trajectory of lifestyle migration: the case of the British residents of southwest France. European Societies, 12(1), 45-64.

Benson, M. (2011). The movement beyond (lifestyle) migration: Mobile practices and the constitution of a better way of life. Mobilities, 6(2), 221-235.

Benson, M., \& O'Reilly, K. (2009). Migration and the search for a better way of life: A critical exploration of lifestyle migration. The Sociological Review, 57(4), 608-625.

Benwell, B., \& Stokoe, E. (2006). Discourse and Identity. Edinburgh: Edinburgh University Press.

Caldas-Coulthard, C. (2008). Body branded: Multimodal identities in tourism advertising. Journal of Language and Politics, 7(3), 451-470.

Cresswell, T. (2004). Place: A Short Introduction. Malden, MA: Blackwell Publishing.

De Fina, A., Schiffrin, D., \& Bamberg, M. (2006). Introduction. In A. De Fina, D. Schiffrin \& M. Bamberg (Eds.), Discourse and Identity. Cambridge: Cambridge University Press.

Dixon, J. A., \& Durrheim, K. (2000). Displacing place-identity: A discursive approach to locating self and other. British Journal of Social Psychology, 39, 27-44.

Elliott, A., \& Urry, J. (2010). Mobile Lives. London: Routledge.

Fairclough, N. (2009). A dialectical-relational approach to critical discourse analysis in social research. In R. Wodak \& M. Meyer (Eds.), Methods of Critical Discourse Analysis (2nd ed., pp. 162-187). London: Sage. 
Fairclough, N., \& Wodak, R. (1997). Critical Discourse Analysis. In T. A. van Dijk (Ed.), Introduction to Discourse Analysis (pp. 258-284). London: Sage.

Giddens, A. (1991). Modernity and Self-Identity: Self and Society in the Late Modern Age. Cambridge: Polity Press.

Giddens, A. (1994). Living in a post-traditional society. In U. Beck, A. Giddens \& S. Lash (Eds.), Reflexive Modernization. Cambridge: Polity Press.

Gorter, D. (2006). Introduction: The study of the Linguistic Landscape as a new approach to multilingualism. In D. Gorter (Ed.), Linguistic Landscape: A New Approach to Multilingualism (pp. 1-7). Clevedon: Multilingual Matters.

Guilianotti, R., \& Robertson, R. (2007). Forms of glocalization: Globalization and the migration strategies of Scottish football fans in North America. Sociology, 4l(1), 133-152.

Harvey, D. (1989). The Condition of Postmodernity. Oxford: Blackwell.

Harvey, D. (1993). From space to place and back again: Reflections on the condition of postmodernity. In J. Bird, B. Curtis, T. Putnam, G. Robertson \& L. Tickner (Eds.), Mapping the Futures: Local Cultures, Global Change (pp. 3-29). London: Routledge.

Hoey, B. (2005). From Pi to Pie: Moral narratives of noneconomic migration and starting over in the postindustrial Midwest. Journal of Contemporary Ethnography, 34(5), 586-624.

Hoey, B. (2009). Pursuing the good life: American narratives of travel and a search for refuge. In M. Benson \& K. O'Reilly (Eds.), Lifestyle Migration: Expectations, Aspirations and Experiences (pp. 31-50). Farnham: Ashgate.

Johnstone, B. (2008). Discourse Analysis (2nd ed.). Malden, MA: Blackwell.

Kaufmann, V., Bergman, M. M., \& Joye, D. (2004). Motility: Mobility as social capital. International Journal of Urban and Regional Research, 28(4), 745-756.

King, R., Warnes, A., \& Williams, A. (2000). Sunset Lives: British Retirement to the Mediterranean. Oxford: Berg.

Koller, V. (2007). "The World's Local Bank': Glocalisation as a strategy in corporate branding discourse. Social Semiotics, 17(1), 111-129.

Koller, V. (2008a). Corporate brands as socio-cognitive representations. In G. Kristiansen \& R. Dirven (Eds.), Cognitive Sociolinguistics: Language Variation, Cultural Models, Social Systems (pp. 389-418). Berlin: Mouton de Gruyter.

Koller, V. (2008b). 'The world in one city': Semiotic and cognitive aspects of city branding. Journal of Language and Politics, 7(3), 431-450.

Kress, G., \& van Leeuwen, T. (1996). Reading Images: The Language of Visual Design. London: Routledge.

Massey, D. (1994). Space, Place and Gender. Cambridge: Polity Press.

Mayes, R. (2008). A place in the sun: The politics of place, identity and branding. Place Branding and Public Diplomacy, 4(2), 124-135.

Morgan, N., \& Pritchard, A. (1998). Tourism Promotion and Power: Creating Images, Creating Identities. Chichester: John Wiley \& Sons.

Morgan, N., \& Pritchard, A. (2004). Meeting the destination branding challenge. In N. Morgan, A. Pritchard \& R. Pride (Eds.), Destination Branding (2nd ed., pp. 59-79). Oxford: Elsevier Butterworth-Heinemann.

Moscovici, S. (1984). The phenomenon of social representations. In R. M. Farr \& S. Moscovici (Eds.), Social Representations (pp. 3-69). Cambridge: Cambridge University Press.

Moscovici, S. (2000). Social Representations: Explorations in Social Psychology. Cambridge: Polity Press.

Neal, T. (2007). Tourism as membrane. Paper presented at the ASA 2007 Thinking Through Tourism Conference, 10-13 April 2007. Available from www.theasa.org/asa07/index.html.

O'Reilly, K. (2000). The British on the Costa del Sol: Transnational Identities and Local Communities. London: Routledge.

O'Reilly, K. (2007a). Emerging tourism futures: Residential tourism and its implications. In C. Geoffroy \& R. Sibley (Eds.), Going Abroad: Travel, Tourism and Migration. 
Crosscultural Perspectives on Mobility (pp. 144-157). Newcastle: Cambridge Scholars Publishing.

O'Reilly, K. (2007b). Intra-European migration and the mobility-enclosure dialectic. Sociology, 41(2), 277-293.

O'Reilly, K. (2007c). The rural idyll, residential tourism and thesSpirit of lifestyle migration. Paper presented at the ASA (Association of Social Anthropologists) 2007 Thinking Through Tourism. Conference, 10-13 April 2007. Available from www.theasa.org/asa07/index.html.

O'Reilly, K. (2009). Hosts and guests, guests and hosts: British residential tourism in the Costa del Sol. In P. Obrador Pons, M. Crang \& P. Travlou (Eds.), Cultures of Mass Tourism: Doing the Mediterranean in the Age of Banal Mobilities (pp. 129-142). Aldershot: Ashgate.

Pine, B. J., \& Gilmore, J. H. (1999). The Experience Economy: Work is Theatre and Every Business is a Stage. Harvard Business School: Harvard Business School Press.

Relph, E. (1976). Place and Placelessness. London: Pion.

Robertson, R. (1994). Globalisation or glocalisation? Journal of International Communication, l(1), 33-52.

Robertson, R. (1995). Glocalization: Time-space and homogeneity-heterogeneity. In M. Featherstone, S. Lash \& R. Robertson (Eds.), Global Modernities (pp. 25-44). London: Sage.

Salazar, N. (2010). Towards an anthropology of cultural mobilities. Crossings: Journal of Migration and Culture, 1, 53-68.

Savage, M., Bagnall, G., \& Longhurst, B. (2005). Globalization and Belonging. London: Sage.

Sheller, M., \& Urry, J. (2004). Introduction: Places to play, places in play. In M. Sheller \& J. Urry (Eds.), Tourism Mobiltities: Places to Play, Places in Play (pp. 1-10). London: Routledge.

Silverstone, R. (1998). Space. Screen, 39(1), 81-84.

Thompson, C. J., \& Arsel, Z. (2004). The Starbucks brandscape and consumers' (anticorporate) experiences of glocalization. Journal of Consumer Research, 31(3), 631-642.

Torkington, K. (2011). The discursive construction of place-identity: British lifestyle migrants in the Algarve. Unpublished $\mathrm{PhD}$ thesis, Lancaster University.

Tuan, Y.-F. (1974). Topophilia. New Jersey: Prentice Hall.

Turismo de Portugal. (2007). Plano Estratégico Nacional de Turismo. Lisboa: Turismo de Portugal, ip.

Urry, J. (1999/2003). Mobile Cultures [Electronic Version]. On-line papers, Department of Sociology, Lancaster University. Retrieved 12/10/2009 from http://www.comp.lancs.ac.uk/sociology/papers/Urry-Mobile-Cultures.pdf.

Urry, J. (2007). Mobilities. Cambridge: Polity.

van Dijk, T. A. (2009). Critical Discourse Studies: A sociocognitive approach. In R. Wodak \& M. Meyer (Eds.), Methods of Critical Discourse Analysis (2nd ed., pp. 62-87). London: Sage.

Wetherell, M. (2001). Themes in discourse research: The case of Diana. In M. Wetherell, S. Taylor \& S. Yates (Eds.), Discourse Theory and Practice: a Reader (pp. 14-28). London: Sage.

Williams, A., \& Patterson, G. (1998). 'An empire lost but a province gained': A cohort analysis of British international retirement in the Algarve. International Journal of Population Geography, 4, 135-155. 


\section{Appendix 1: Figures}

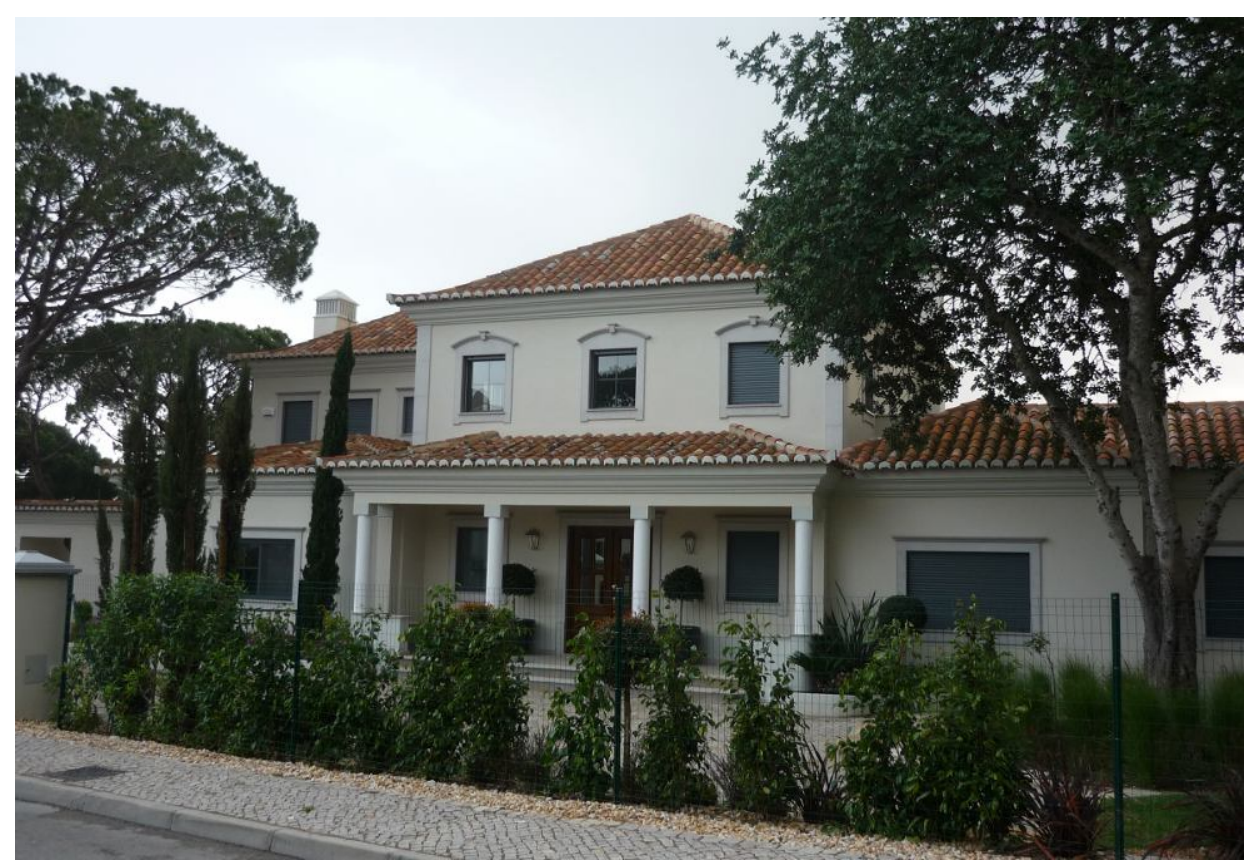

Figure 1: New house in Vale do Lobo, Algarve

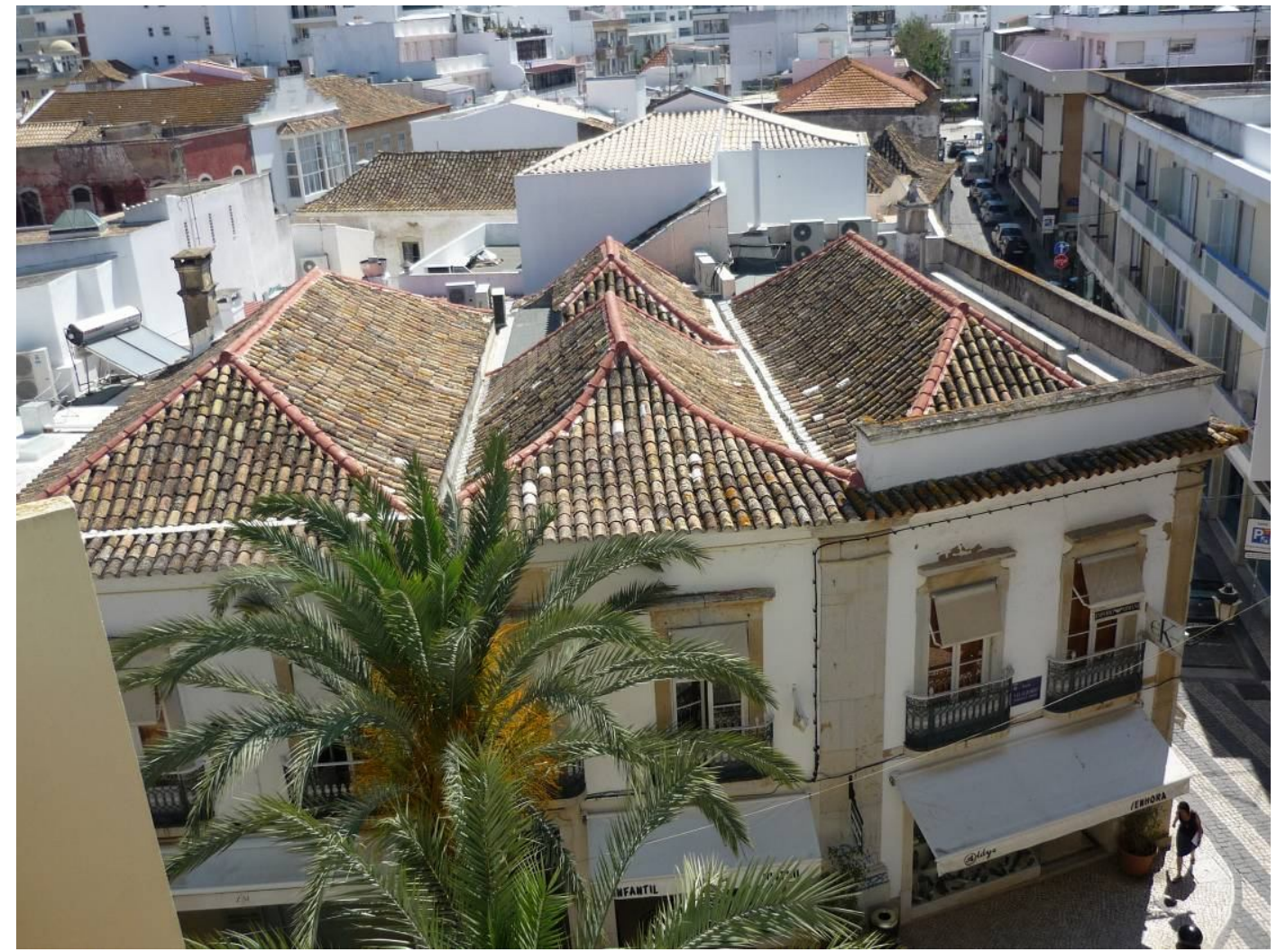

Figure 2: Old town houses, Faro, Algarve 


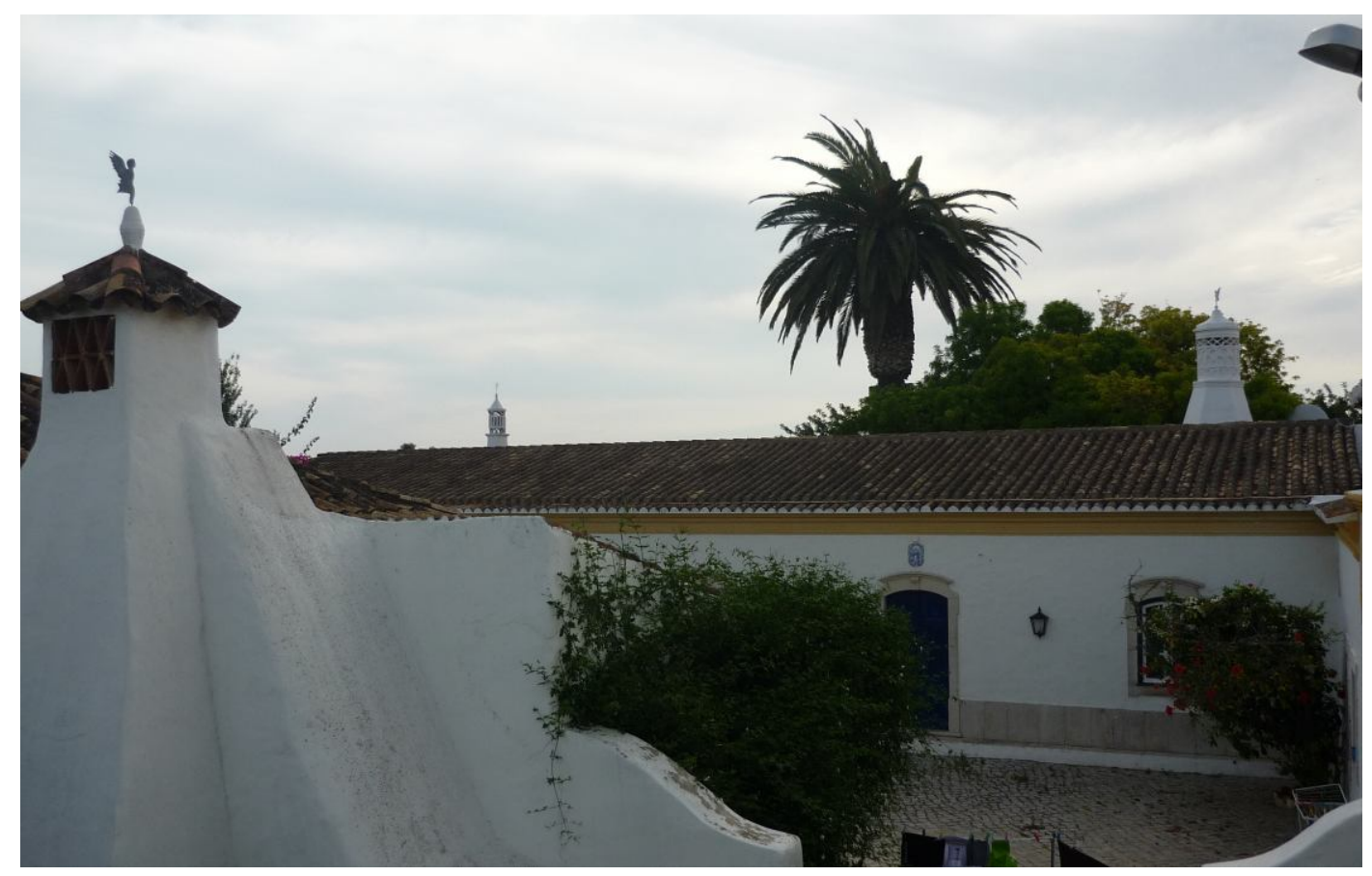

Figure 3: Algarvian chimneys

\section{Appendix 2: Transcription conventions}

[ ] Square brackets indicate overlapping turns

(.) A dot in parentheses indicates a brief pause

a dash indicates a false start or cut-off

$\underline{\text { Oh }} \quad \underline{\text { Underlining indicates stress (volume or pitch) }}$

$:$ Colons indicate prolongation of immediately prior sound 